\title{
Antioxidant Activity of Allium scorodoprasum L. subsp. rotundum (L.) STEARN Plant Grown in Turkey
}

\author{
Bahtınur Taşcı ${ }^{1, a, *}$, Halil Kütük ${ }^{2, b}$, İlkay Koca ${ }^{3, c}$ \\ ${ }^{1}$ Department of Nutrition and Dietetics, Faculty of Health Sciences, Ondokuz Mayls University, 55139 Samsun, Turkey \\ ${ }^{2}$ Department of Chemistry, Faculty of Arts and Sciences, Ondokuz Mayls University, 55139 Samsun, Turkey. \\ ${ }^{3}$ Department of Food Engineering, Faculty of Engineering, Ondokuz Mayıs University, 55139 Samsun, Turkey
}

*Corresponding author

\begin{tabular}{|c|c|}
\hline A R T I C L E INFO & A B S T R A C T \\
\hline $\begin{array}{l}\text { Keywords: } \\
\text { Allicin } \\
\text { Allium } \\
\text { Antioxidant activity } \\
\text { Total phenolics } \\
\text { Körmen }\end{array}$ & $\begin{array}{l}\text { Allium scorodoprasum L. subsp. rotundum (L.) STEARN is a medical and aromatic plant which } \\
\text { grows naturally in various countries of the world. The purpose of this study was to determine the } \\
\text { natural antioxidant content and antioxidant activity of Allium scorodoprasum L. subsp. rotundum } \\
\text { (L.) STEARN plant, an Allium subspecies of the Alliaceae family. Plants which grow naturally in } 7 \\
\text { different locations of } 3 \text { cities (Samsun, Nevşehir and Tokat) of Turkey were used in the study. The } \\
\text { purpose of this study was to determine the natural antioxidant content and antioxidant capacity of } \\
\text { wild leek plant, an Allium subspecies of the Alliaceae family, which grows in three different cities } \\
\text { (Samsun, Nevşehir and Tokat). The material of the study consists of } 42 \text { wild leek samples from } 7 \\
\text { different locations of Samsun, Tokat and Nevşehir. Some physicochemical characteristics and } \\
\text { antioxidant features of both bulbs and leaves of samples were determined separately; allicin, an } \\
\text { organosulfur compound, was specified qualitatively and thermal behaviours of the samples were } \\
\text { monitored through TGA/DSC analysis. As a result of the analyses conducted, in the bulb and leaf } \\
\text { parts of the samples, total phenolic matter values were } 254.51-927.81 \text { and } 1929.05-19645.24 \text { mg/kg, } \\
\text { FRAP was } 0.80-5.20 \text { and } 14.31-47.83 \text { mM TE/g, DPPH free radical scavenger effect was } 0.99-9.02 \\
\text { and } 36.61-241.06 \mu \text { mol TE/g and ascorbic acid content was } 29.14-314.01 \text { mg/kg and } 200.64- \\
1383.16 \text { mg/kg, respectively. These data reveal that the leaf's of } \text { A. scorodoprasum subsp. rotundum } \\
\text { plants are rich in antioxidants. In conclusion, it was found that the antioxidant activity of the plants } \\
\text { differs significantly in terms of the parts of the plant and growth location. }\end{array}$ \\
\hline
\end{tabular}

Türk Tarım - Gıda Bilim ve Teknoloji Dergisi 7(10): 1561-1567, 2019

\section{Allium scorodoprasum L. subsp. Rotundum (L.) STEARN Bitkisinin Antioksidan Özelliklerinin Tayini}

\begin{tabular}{|c|c|}
\hline M A K A L E B İ L G İ S İ & Ö Z \\
\hline $\begin{array}{l}\text { Anahtar Kelimeler: } \\
\text { Allisin } \\
\text { Allium } \\
\text { Antioksidan aktivite } \\
\text { Toplam fenol } \\
\text { Körmen }\end{array}$ & 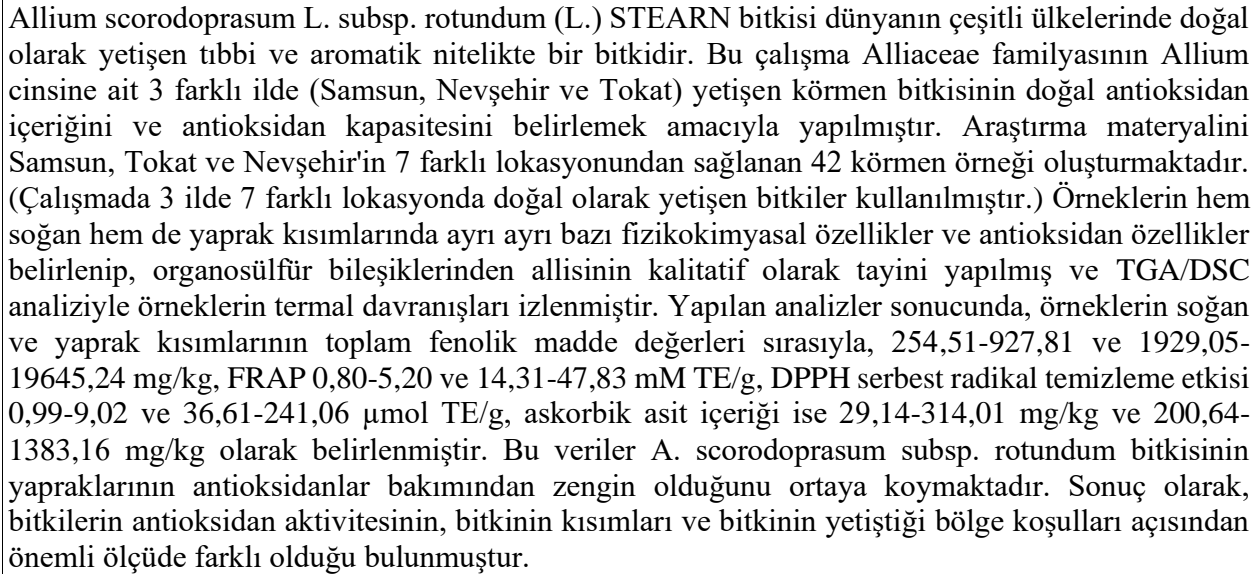 \\
\hline
\end{tabular}




\section{Introduction}

Since ancient times, people have developed medicines for the treatment of diseases. They used natural products such as plants, fungi, animals, microorganisms and marine organisms to prepare these drugs (Sevindik et al., 2017; Pehlivan and Sevindik, 2018). A. scorodoprasum subsp. rotundum, a subspecies of the Alliaceae family, is a medical and aromatic plant which grows naturally in various countries of the world, including our country. A. rotundum belongs to Allium species. Allium species is the widest and the most characteristic member of Alliaceae family, which includes more than 800 species, 15 subspecies and 72 sections (Fritsch et al., 2010; Miryeganeh and Movafeghi, 2009). The members of this species are consumed since the old ages because of their taste and aroma ingredients. While a great number of its species are preferred widely in folk medicine, this plant which has economical value is also used as herbal medicine and decorative plant. These plants are generally bulbous and perennial (Zouari et al., 2013; Mitic et al., 2014). They have a wide distribution in the world, especially in the northern hemisphere (Mehrabi and Nasab, 2012). Allium plants are rich in terms of thiosulphate and organosulphur compounds which play an important role in cell biochemistry (Sahu, 2002). These plants protect against a great number of diseases such as cancer, obesity, cardiovascular diseases, diabetes, hypercholesterolemia and hypertension (Lanzotti, 2006; Pardo et al., 2007).

A. rotundum, which has medical properties, is known as wild leek in the world (Mehrabi and Nasab, 2012). Studies in literature about $A$. rotundum, which is consumed due to its health effects besides its use as food in public, are limited. The purpose of this study was to determine the natural antioxidant content and antioxidant activity of $A$. scorodoprasum subsp. rotundum plant and to determine the presence of allicin, which is one of the organosulphur compounds.

\section{Material and Methods}

\section{Sample Collection and Identification}

Plant materials were collected in April till June (2015) from different regions of Turkey. The plants were collected from 7 different locations in 3 different cities as Samsun (latitude $41^{\circ}$ $21^{\prime} 3.3732^{\prime \prime} \mathrm{N} X 36^{\circ} 9^{\prime} 58.2336 " \mathrm{~W}, 300-700 \mathrm{~m}$ above sea level), Nevşehir (latitude $38^{\circ} 38^{\prime} 55.5000^{\prime \prime} \mathrm{N} X 34^{\circ} 50^{\prime}$ 10.3236", 800-1100 $\mathrm{m}$ above sea level) and Tokat (latitude $40^{\circ}$ $32^{\prime} 59.9964 " \mathrm{~N}$ X $37^{\circ} 10^{\prime} 0.0048^{\prime \prime} \mathrm{W}, 1300-1700 \mathrm{~m}$ above sea level). The plants were identified at Ondokuzmayıs University, Faculty of Science and Arts, Department of Botanic at the Department of Biology. After the plants taken to the laboratory were washed and the extra water was removed, bulbs and fresh leaves were prepared separately for analysis.

\section{Preparation of Extracts for Antioxidant Activity}

Antioxidant compounds were extracted with aqueous methanol (80\%) using ultrasonic bath (Bandelin, Berlin, Germany) for $20 \mathrm{~min}$ at room temperature. The extracts was filtered through $0.45 \mu \mathrm{m}$ teflon filter.

\section{Colour Analysis}

The colour of the plants was measured using a chromameter (Model Minolta CR-400, Japan) which has been calibrated using a Standard white plate (No:
19633162) to determine the value of $L^{*}$ (Lightness: $L^{*}=100$ for white and 0 for black), $a *$ (redness/greenness axis: positive $a^{*}$ is red and negative $a^{*}$ is green), $b^{*}$ (yellowness/ blueness axis: positive $b^{*}$ is yellow).

\section{Dry Matter Determination}

For determination of the dry matter content, approximately $5 \mathrm{~g}$ of homogenised sample was dried in a vacuum oven at $70^{\circ} \mathrm{C}$ less than $100 \mathrm{mmHg}$ pressures until reaching constant weight (AOAC, 2000).

\section{Determination of $\mathrm{pH}$}

The $\mathrm{pH}$ of the plants extracts was diluted with 1:10 distilled water and measured using a $\mathrm{pH}$ meter (Eutech Cyberscan, Singapore). $\mathrm{pH}$ was measured at room temperature and stirred before the reading was taken. Calibration of the $\mathrm{pH}$ meter was carried out using $\mathrm{pH} 4$ and 7 buffers (AOAC, 2000).

\section{Determination of Ascorbic acid}

Ascorbic acid (AA) content was determined by Lee et al. (1999)'s method. In order to do this, a certain amount of sample was weighed and extracted with $2.5 \%$ phosphoric acid solution and centrifuged at $+4^{\circ} \mathrm{C}$ and 6500 rpm for 10 minutes. The clear part was passed from 0.22 $\mu \mathrm{m}$ teflon filter and given to HPLC device. The mobile phase was taken as $2 \% \mathrm{KH}_{2} \mathrm{PO}_{4}$, flow rate was taken as 0.5 $\mathrm{mL} / \mathrm{min}$, wave length was taken as $245 \mathrm{~nm}$ and the injection volume was taken as $10 \mu \mathrm{L}$. Calibration curve prepared with different concentrations of ascorbic acid solutions which were prepared with pure ascorbic acid (99\% pure, Carlo Erbaa, Code No: 390604) were used in calculating the results. Retention time of pure ascorbic acid at $245 \mathrm{~nm}$ was found to be 7.01 minutes on average.

HPLC (Shimadzu Corporation, Kyoto, Japan) system which consisted of LC-20AT pump unit, SPD-M20A PDA detector, SIL-20A automatic sampler, CBM-20A system control unit and CTO-10ASvp colon oven were used for ascorbic acid analysis. ACEC18 (250 mm, $4.6 \mathrm{~mm}, 5 \mu \mathrm{m})$ was used as the colon in the analysis. Ultra-pure water obtained with Millipore, Direct-QUV3 system was used in mobile phase and samples.

\section{Determination of Total Phenolics (TPO)}

Total phenolic contents of the samples were determined by the Folin-Ciocalteu procedures according to the method of Mladenović et al. (2011) with minor changes. In brief, Folin-Ciocalteu reagent was diluted 10-fold with deionised water. The $80 \%$ methanolic plant extracts $(0.5 \mathrm{~mL})$ were mixed with $2.5 \mathrm{~mL}$ of the diluted Folin-Ciocalteu reagent and incubated for $10 \mathrm{~min}$ at room temperature. Then, $2 \mathrm{~mL}$ of $7.5 \%$ sodium carbonate (w/v) solution was added. The mixture was allowed to stand in the dark for $120 \mathrm{~min}$ before measuring the absorbance at $765 \mathrm{~nm}$ using an UV-Visible spectrophotometer (Thermospectronic-Helios Gamma, UK) against a blank, containing deionised water instead of sample extract. TPO values were determined from a calibration curve prepared with a series of gallic acid standards $(0,5,10,20,30,40$ and $50 \mathrm{mg} / \mathrm{L})$. Results are expressed as $\mathrm{mg}$ of gallic acid equivalents $/ \mathrm{kg}$ dry weight (mg GAE/kg DW). 


\section{Determination of Antioxidant Activity}

The bulb and leaf parts of the plants were subjected to an antioxidant activity assay. Two methods were used to determine the antioxidant activity: Ferric Reducing/Antioxidant Power (FRAP) and the 2,2diphenyl-picrylhydrazyl (DPPH) radical-scavenging activity tests.

\section{FRAP Assay}

FRAP of the methanolic extracts was evaluated according to the method of Gao et al. (2000) with some modification. The FRAP reagent was prepared from $1 \mathrm{~mL}$ of a TPTZ solution $(10 \mathrm{mM})$ in hydrochloric acid $(40 \mathrm{mM})$ and $1 \mathrm{~mL}$ of a $\mathrm{FeCl}_{3}$ solution $(20 \mathrm{mM})$ mixed with $10 \mathrm{~mL}$ of an acetate buffer $(300 \mathrm{mM}, \mathrm{pH} 3.6)$. For the determination of the antioxidant activity, the FRAP reagent $(950 \mu \mathrm{L})$ was mixed with $50 \mu \mathrm{L}$ of the sample extracts, Trolox (6-hydroxy-2,5,7,8tetramethylchromane-2-carboxylic acid) standard or control ( $80 \%$ methanol). The reaction mixture was allowed to stand for $5 \mathrm{~min}$ at room temperature (ca. $20^{\circ} \mathrm{C}$ ) before the absorbance at $593 \mathrm{~nm}$ was measured. A calibration curve was performed over a range of $0-500 \mu \mathrm{mol} / \mathrm{L}$ concentration of Trolox. The results were expressed as $\mu \mathrm{mol}$ Trolox Equivalents/g dry weight sample.

\section{DPPH Radical Scavenging Activity}

The free radical-scavenging activity was determined using 2,2-diphenyl-1-picrylhydrazyl radical (DPPH) according to Tural and Koca, (2008), with some minor revisions. Methanolic extracts $(50 \mu \mathrm{L})$ were added to $1 \mathrm{~mL}$ of DPPH solution $\left(6 \times 10^{-5} \mathrm{M}\right.$ in methanol) and the absorbance of the DPPH solution was determined at 517 $\mathrm{nm}$ after $120 \mathrm{~min}$ of incubation at room temperature. Methanolic solutions of Trolox $(80 \%)$ in a range of $0-500$ $\mu \mathrm{mol} / \mathrm{L}$ were used for calibration to compare the antioxidant activity of the extracts. The results were expressed as $\mu \mathrm{mol}$ Trolox equivalents/g dry weight sample ( $\mu \mathrm{mol}$ Trolox/g DW).

\section{Determination of Organosulphur (Alliin and Allicin)}

The plants were directly analysed with IR according to $\mathrm{Lu}$ et al. (2011a) and the absorption bands of organosulphur compounds were determined. Fourier Transform Infrared (FT-IR) spectra were obtained by using a Perkin ELMER FT-IR spectrometer (PIKE MIRacle TM ATR). Measurements were carried out at $20^{\circ} \mathrm{C}$. Infrared spectra were recorded from 4000 to $650 \mathrm{~cm}^{-1}$.

\section{TGA/DSC (Simultaneous Differential Thermal} Analysis System (SDT))

In TGA/DSC analysis, the changes that occurred in the sample with temperature increase were monitored. TA Instruments Q600 model simultaneous analysis device was used for this purpose. Capless, reference and sample pans made of platinum were used for measurement. The mass of samples was taken as $17 \mathrm{mg}$. The analyses were conducted at $\mathrm{N}_{2}$ atmosphere. Gas flow speed was adjusted as 20 $\mathrm{mL} / \mathrm{min}$. Measurement was conducted between a temperature range of 25 and $1000^{\circ} \mathrm{C}$ (Al-Wafi, 2005).

\section{Statistical Analysis}

Analyses were performed in triplicates. SPSS 21 package program (two ways ANOVA) was used to compare the analysis results of samples which were harvested from different locations of 3 cities and grouped in two (bulb and leaf). Duncan's multiple range test was used to compare the leaf and bulb parts of the averages of locations. Two ways Pearson method was used to analyse the correlation between natural antioxidants and antioxidant activity.

\section{Results and Discussion}

\section{Physicochemical Properties of the Plants}

Physicochemical properties of the plants harvested from 3 different cities in terms of both bulb and leaf parts are given in Table 1.

As can be seen from the Table, lightness value was between 42.34 and 63.36 in bulbs, between 31.90 and 44.58 in leaves; greenness value was between -0.11 and 0.744 in bulbs, between -5.68 and -11.86 in leaves and yellowness value was between 2.78 and 9.05 in bulbs and between 10.75 and 19.45 in leaves. No statistically significant difference was found between the location and greenness values ( $\mathrm{P}>0.05)$. Dry matter (D.M., \%) changed between $20.29 \%$ and $31.71 \%$ in bulbs and between $12.88 \%$ and $33.20 \%$ in leaves. Changes in dry matter were big in terms of location and the differences between cities were found to be statistically significant $(\mathrm{P}<0.05)$. $\mathrm{pH}$ value was found to be between 6.51 and 6.75 in bulbs and between 5.14 and 5.76 in leaves. While the $\mathrm{pH}$ values of bulbs showed less variation, $\mathrm{pH}$ values of leaves varied more and this variation was found to be statistically significant $(\mathrm{P}<0.05)$.

Table 1 Some physicochemical properties of different parts of the plants were grown in different locations (mean \pm standard deviation, variations) $(\mathrm{n}=7)$

\begin{tabular}{l|lccc}
\hline Parameters & Parts & A & B & C \\
\hline \multirow{2}{*}{$L^{*}$} & bulbs & $61.87 \pm 1.15^{\mathrm{a}}(59.76-63.36)$ & $52.80 \pm 6.85^{\mathrm{b}}(42.34-61.21)$ & $56.40 \pm 2.97^{\mathrm{b}}(51.35-58.95)$ \\
& leaves & $38.08 \pm 2.57(34.75-40.92)$ & $37.03 \pm 4.13(32.84-44.58)$ & $36.90 \pm 4.33(31.90-43.06)$ \\
$a^{*}$ & bulbs & $-0.39 \pm 0.26(-0.13-(-) 0.74)$ & $-0.29 \pm 0.17(-0.11-(-) 0.53)$ & $-0.44 \pm 0.20(-0.19-(-) 0.86)$ \\
& leaves & $-9.43 \pm 1.27(-8.11-(-) 11.86)$ & $-9.49 \pm 0.66(-8.65-(-) 10.33)$ & $-8.48 \pm 1.79(-5.68-(-) 10.38)$ \\
$b^{*}$ & bulbs & $4.79 \pm 0.94^{\mathrm{b}}(2.78-5.66)$ & $5.17 \pm 0.46^{\mathrm{b}}(4.62-5.60)$ & $7.31 \pm 1.23^{\mathrm{a}}(5.71-9.05)$ \\
& leaves & $12.57 \pm 1.85^{\mathrm{b}}(10.75-16.13)$ & $15.83 \pm 2.05^{\mathrm{a}}(13.48-19.45)$ & $13.78 \pm 1.96^{\mathrm{ab}}(11.69-16.73)$ \\
D.M., \% & bulbs & $28.00 \pm 1.56^{\mathrm{b}}(26.05-30.34)$ & $20.75 \pm 0.42^{\mathrm{c}}(20.29-21.58)$ & $29.65 \pm 1.32^{\mathrm{a}}(28.39-31.71)$ \\
& leaves & $16.69 \pm 3.42^{\mathrm{b}}(12.88-23.90)$ & $17.67 \pm 1.05^{\mathrm{b}}(16.62-19.88)$ & $29.10 \pm 2.26^{\mathrm{a}}(26.94-33.20)$ \\
$\mathrm{pH}$ & bulbs & $6.66 \pm 0.06(6.55-6.75)$ & $6.63 \pm 0.06(6.55-6.73)$ & $6.66 \pm 0.08(6.51-6.74)$ \\
& leaves & $5.46 \pm 0.16^{\mathrm{b}}(5.25-5.75)$ & $5.37 \pm 0.10^{\mathrm{b}}(5.14-5.45)$ & $5.65 \pm 0.076^{\mathrm{a}}(5.54-5.76)$ \\
\hline
\end{tabular}

*There is no statically difference between the averages shown in the same line and letters $(\mathrm{P}>0.05)$, **A: Samsun location, $\mathrm{B}$ : Nevşehir location, $\mathrm{C}$ : Tokat location 
Table 2 Antioxidant properties (in dry weight) of different parts of the plants grown different locations (mean \pm standard deviation, variations) $(\mathrm{n}=7)$

\begin{tabular}{l|lcccccc}
\hline \multirow{2}{*}{ Parameters } & $\mathrm{P}$ & \multicolumn{2}{|c}{$\mathrm{A}$} & \multicolumn{3}{c}{$\mathrm{B}$} & \multicolumn{2}{c}{$\mathrm{C}$} \\
& & $\mathrm{M}+\mathrm{St}$ & $\mathrm{V}$ & $\mathrm{M}+\mathrm{St}$ & $\mathrm{V}$ & $\mathrm{M}+\mathrm{St}$ & $\mathrm{V}$ \\
$\mathrm{TPO}$ & $\mathrm{B}$ & $481.04 \pm 139.39$ & $302.00-645.81$ & $596.62 \pm 90.05$ & $515.02-780.68$ & $649.46 \pm 265.28$ & $254.51-927.81$ \\
$\mathrm{mg} / \mathrm{kg}$ & $\mathrm{L}$ & $17400.34 \pm 1489.04^{\mathrm{a}}$ & $15621.43-19645.24$ & $7570.40 \pm 694.62^{\mathrm{b}}$ & $6907.14-8645.24$ & $2110.00 \pm 205.00^{\mathrm{c}}$ & $1929.05-2557.62$ \\
$\mathrm{AA}$ & $\mathrm{B}$ & $80.81 \pm 26.89$ & $51.50-127.62$ & $95.86 \pm 80.06$ & $29.14-225.13$ & $125.05 \pm 121.63$ & $29.59-314.01$ \\
$\mathrm{mg} / \mathrm{kg}$ & $\mathrm{L}$ & $762.37 \pm 310.36^{\mathrm{a}}$ & $514.55-1383.16$ & $271.60 \pm 62.87^{\mathrm{c}}$ & $200.64-365.59$ & $495.16 \pm 90.35^{\mathrm{b}}$ & $357.34-605.53$ \\
$\mathrm{FRAP}$ & $\mathrm{B}$ & $3.92 \pm 0.84^{\mathrm{a}}$ & $3.11-5.20$ & $2.90 \pm 0.59^{\mathrm{b}}$ & $1.99-3.59$ & $1.74 \pm 0.53^{\mathrm{c}}$ & $(0.80-2.51$ \\
$\mu \mathrm{mol} \mathrm{TE} / \mathrm{g}$ & $\mathrm{L}$ & $42.95 \pm 3.28^{\mathrm{a}}$ & $39.30-47.83$ & $19.37 \pm 3.09^{\mathrm{b}}$ & $15.22-22.98$ & $16.08 \pm 1.40^{\mathrm{c}}$ & $(14.31-18.53$ \\
$\mathrm{DPPH}$ & $\mathrm{B}$ & $6.23 \pm 1.12^{\mathrm{a}}$ & $5.24-8.28$ & $2.06 \pm 0.83^{\mathrm{b}}$ & $0.99-3.11$ & $6.07 \pm 1.97^{\mathrm{a}}$ & $(3.21-9.02$ \\
$\mu \mathrm{mol} \mathrm{TE} / \mathrm{g}$ & $\mathrm{L}$ & $144.81 \pm 45.26^{\mathrm{a}}$ & $111.05-241.06$ & $40.64 \pm 5.19^{\mathrm{c}}$ & $36.61-51.54$ & $75.42 \pm 10.90^{\mathrm{b}}$ & $(54.07-86.39$ \\
\hline
\end{tabular}

P: Parts, B: bulbs, L: leaves, M+St: mean \pm standard deviation, V: variations, ${ }^{*}$ There is no statically difference between the averages shown in the same line and letters $(\mathrm{P}>0.05), * * A$ : Samsun location, B: Nevşehir location, $\mathrm{C}$ : Tokat location

Akinwande and Olatunde, (2015) recorded $\mathrm{pH}$ values in three different onions and garlics as 5.89, 5.90, 5.85 and 6.61 , respectively. It was found that the $\mathrm{pH}$ values found in the bulb parts of the samples of this study were higher than those found in Akinwande and Olatunde, (2015)'s study, while the results were in parallel with garlic results.

\section{Antioxidant Properties}

Antioxidant analysis results of the bulb and leaf parts of the plants are given in Table 2 .

Among all the cities, the lowest and highest total phenol content of the samples were between 254.51 and 927.81 and between 1929.00 and $19645.24 \mathrm{mg} / \mathrm{kg}$, respectively, while lowest and highest FRAP values were between 0.80 and 5.20 and between 14.31 and $47.83 \mathrm{mM} \mathrm{TE} / \mathrm{g}$, lowest and highest ascorbic acid content was between 29.14 and $314.01 \mathrm{mg} / \mathrm{kg}$ and between 200.64 and $1383.16 \mathrm{mg} / \mathrm{kg}$ and lowest and highest DPPH free radical scavenger effect was between 0.99 and 9.02 and between 36.61 and $241.06 \mu \mathrm{mol} \mathrm{TE} / \mathrm{g}$.

Lu et al. (2011b) found the total phenol content analysis results of 5 different garlic samples as 15.61, 19.69, 17.35, 16.20 and $15.62 \mathrm{mg}$ gallic acid/g, respectively. Mladenovic et al. (2011) found the total phenol content of the bulb and leaf parts of Allium porrum L. species as 69.46 and 45.39 $\mathrm{mg}$ GAE/g. Ashwini et al. (2013) found the total phenol contents of two different onions (A. сера) as 15.7-34.7 $\mathrm{mg} / \mathrm{g}$ GAE respectively. Mitic et al. (2014) found the total phenolic content of the methanol extract of bulb part of Allium scorodoprasum plant as $36.692 \mu \mathrm{g} \mathrm{GA} / \mathrm{mg}$.

$\mathrm{Lu}$ et al. (2011a) found the FRAP values of white, yellow, red, sweet and pearl onion as 4.38, 5.32, 5.76, 2.48 and $6.40 \mu \mathrm{mol}$ Trolox/g FW, respectively. Ashwini et al., (2013) found the FRAP values of two different onion types (A. сера) as 0.9 and $3.3 \mu \mathrm{M} / 100 \mathrm{mg}$, respectively.

Colina-Coca et al. (2014) found the Vitamin C levels of crushed and chopped onions between $3.92 \mathrm{mg} / 100 \mathrm{~g}$ and 5.03 $\mathrm{mg} / 100 \mathrm{~g}$. Venkadachalam et al. (2014) found the ascorbic acid level of red onion as $28.12 \mathrm{mg} / 100 \mathrm{~g}$. Akinwande and Olatunde, (2015) found the Vitamin C levels of three types of onion (Allium cepa L.) and garlic (Allium sativum L.) as 20.67 $\mathrm{mg} / 100 \mathrm{~g}, 18.15 \mathrm{mg} / 100 \mathrm{~g}$ and $8 \mathrm{mg} / 100$, respectively. The values reported by Colina-Coca et al. (2014), Akinwande and Olatunde, (2015) and Venkadachalam et al. (2014) are in parallel with our values.

Lu et al. (2011a) found the DPPH free radical scavenger effect of white, yellow, red, sweet and pearl onion as 3.04, 4.56, 5.20, 1.42 and 5.71 $\mu \mathrm{mol}$ Trolox/g FW, respectively. Lu et al., (2011b) found the DPPH free radical scavenger effect of a total of 5 different garlics, 4 types of garlic grown in 4 different regions (California, Washington, New York and Oregon) and elephant garlic grown in California as 7.60, 9.78, 9.47, 8.95 and $6.95 \mu \mathrm{mol}$ Trolox/g FW, respectively. Ashwini et al. (2013) reported the DPPH free radical scavenger effect of two different types of onions (A. cepa) as $6.5 \%$ and $11.8 \%$.

Likewise, the total antioxidant status of Sativa multicaulis cultivated in Turkey has been investigated using Rel Assay Kits. As result, Sativa multicaulis displayed an important antioxidant activity, estimated at $6.434 \mathrm{mmol}$ Trolox equiv./L (Pehlivan and Sevindik, 2018). When compared the antioxidant status of Allium scorodoprasum and Sativa multicaulis, it can be assumed that the FRAP values of Allium scorodoprasum detected in the present study were higher. Similarly, Sevindik et al. (2017) have evaluated the antioxidant capacity and the total antioxidant status of the ethanolic extracts of Mentha longifolia L. Hudson subsp. Longifolia grown in Turkey with the application of DPPH assay and Rel Assay Kit, respectively. Their study revealed that the DPPH values of Mentha longifolia L. Hudson subsp. Longifolia varied from $48.46 \%$ to $92.94 \%$ for the sample concentrations ranged between 25 to $200 \mu \mathrm{g} / \mathrm{mL}$, while the values of the total antioxidant status were found to be ranged between 1.809 and $3.628 \mathrm{mmol}$ Trolox equiv./L for different locations. These findings indicated that these plants have high antioxidant activity, however, the species of Allium studied in the present study displayed higher antioxidant activity.

In the correlation analysis conducted based on Pearson method, positive correlation was found between FRAP values and total phenolic matter $(\mathrm{r}=0.960 * *)$, ascorbic acid $\left(\mathrm{r}=0.643^{* *}\right)$ and DPPH $\left(\mathrm{r}=0.826^{* *}\right)$. Positive correlation was found between DPPH and total phenolic matter $\left(\mathrm{r}=0.713^{* *}\right)$, FRAP $\left(\mathrm{r}=0.826^{* *}\right)$ and ascorbic acid $(\mathrm{r}=0.870 * *)$. The correlation between total phenol and ascorbic acid $(\mathrm{P}<0.05)$ is statistically significant while all the other correlations are statistically very significant $(\mathrm{P}<0.01)$. No statistically significant correlation was found between any of the characteristics according to the Pearson method conducted in the bulb part of the plants.

\section{IR and TGA Analysis Results}

For the qualitative analysis of the organosulphur compounds of bulb and leaf parts of the plants harvested from different cities, measurements of all samples were made in FT-IR spectrophotometry and their absorption bands were determined. The spectra of the bulb and leaf parts of the plant are given in Figure 1 and Figure 2. 


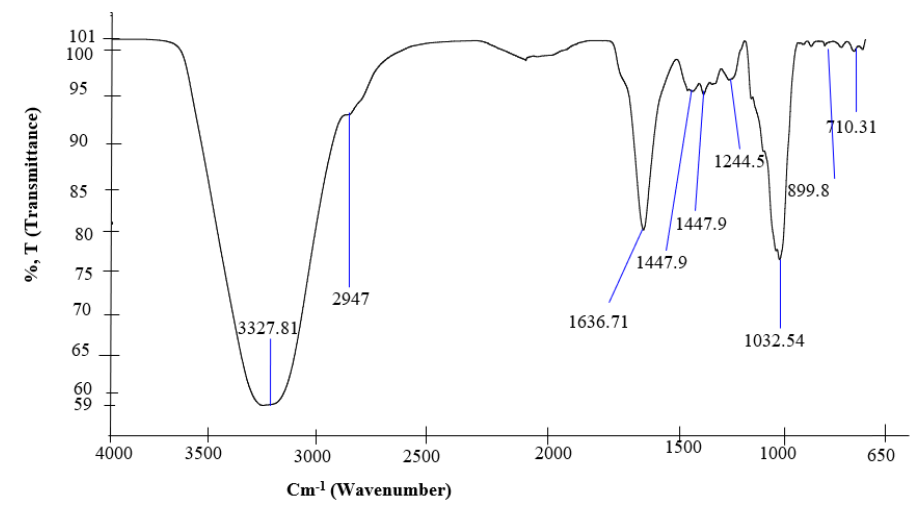

Figure 1 Spectra of fourier transform infrared (FTIR) of the bulb part of the plants (A village).

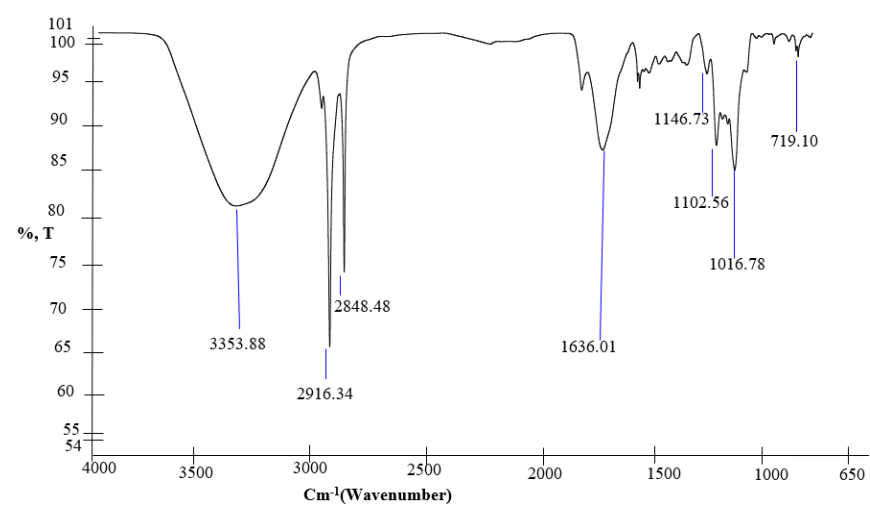

Figure 2 Spectra of fourier transform infrared (FTIR) of the leaf part of the plants (A village)

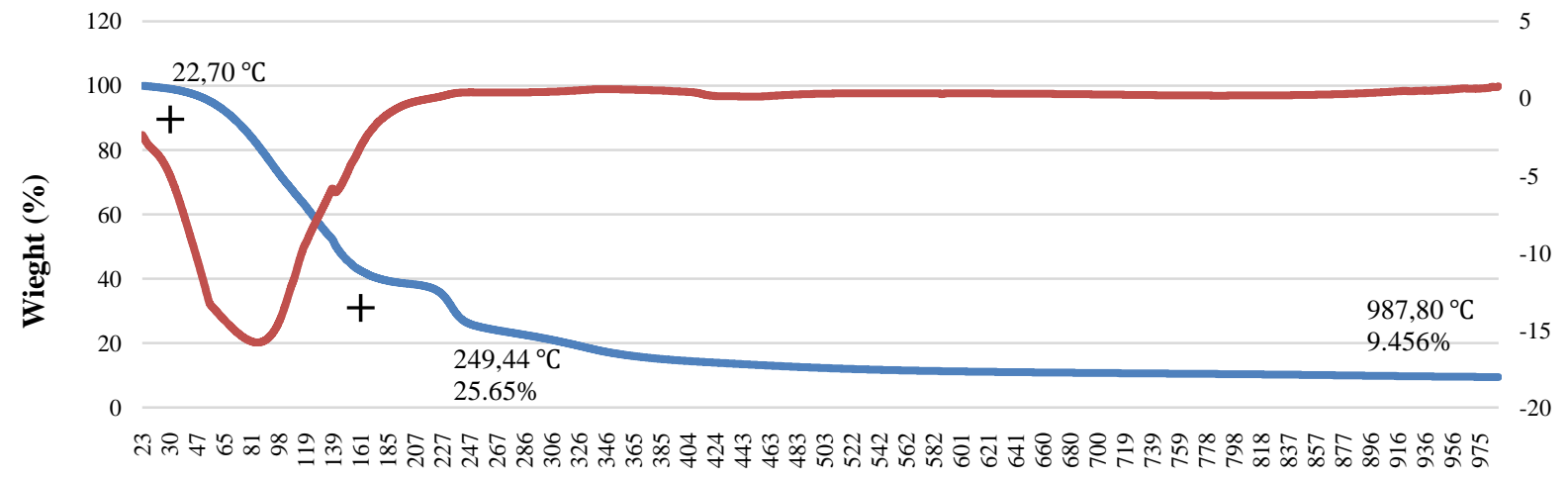

Tempature $\left({ }^{\circ} \mathrm{C}\right)$

Weight $(\%) \quad$ Heat Flow (W/g)

Figure 3 Thermogram of bulbs of the plants (A village)

The difference between leaf parts of the samples was found to be statistically significant in terms of cities $(\mathrm{P}<0.05)$.

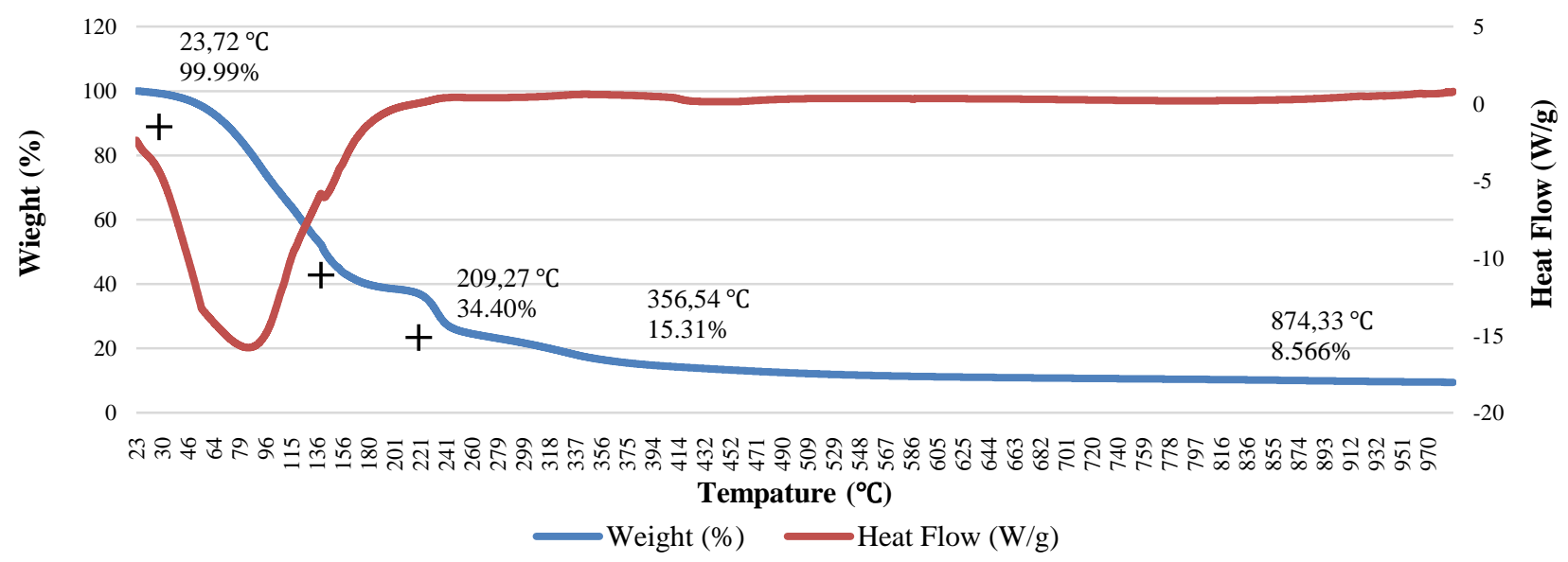

Figure 4 Thermogram of leaves of the plants (A village) 
Different spectra were obtained from the leaf and bulb parts. The peaks obtained and their bonds can be interpreted as follows: first peak $3327.81 \mathrm{~cm}^{-1}\left(\mathrm{CH}=\mathrm{CH}_{2}\right)$ at the head part spectrum of garlic belongs to allyl group bond, second peak $2947 \mathrm{~cm}^{-1}$ belongs to aliphatic $\mathrm{CH}$ group bond, third peak $1636.71 \mathrm{~cm}^{-1}$ belongs to $\mathrm{C}=\mathrm{C}$ bond, fourth peak belongs to $1032.54 \mathrm{~cm}^{-1} \mathrm{~S}=\mathrm{O}$ bond, fifth peak belongs to $899.87 \mathrm{~cm}^{-1} \mathrm{C}-\mathrm{S}$ bond and the sixth peak belongs to $710.31 \mathrm{~cm}^{-1} \mathrm{~S}-\mathrm{S}$ bond.

The second peak at the spectrum of the leaf part of the plant 2916.34-2848.48 $\mathrm{cm}^{-1}$ (double peak) belongs to $\mathrm{NH}_{2}$ group. The other peaks at the leaf part were interpreted the same with the bulb part. When the areas where the functional groups in the formula of allicin and allyl structural form gave their peaks were solved, the presence of both compounds was found as a result of spectral measurement. In the leaf part, allyl group is more due to $\mathrm{NH}_{2}$ bond while allicin compound is more in the bulb part.

Pirak et al. (2012) measured the characteristic frequency of allicin at IR spectrum between 1364 and 1087 $\mathrm{cm}^{-1}$. In their study, Songsungkan and Chanthai, (2014) reported the peaks and their functional groups as $(\mathrm{S}=\mathrm{O})$ $1026-1030 \mathrm{~cm}^{-1},(\mathrm{~S}-\mathrm{H}) 2382 \mathrm{~cm}^{-1},(\mathrm{C}=\mathrm{C}) 1648 \mathrm{~cm}^{-1}$ and $(\mathrm{C}-$ C) $1465 \mathrm{~cm}^{-1}$. In their study, Lu et al., (2011b) measured the characteristic peaks of allicin as 3082, 1634, 1423, $1218,986,920,721$ and $477 \mathrm{~cm}^{-1}$.

\section{TGA/DSC Analysis Results}

Figure 3 gives the thermogram of the bulb part of the plant grown in Samsun while Figure 4 gives the thermogram of the leaf part of the same sample.

Thermal behaviours of the sample according to Figure 3 are as follows: in the first step, weight loss started at $25^{\circ} \mathrm{C}$ and was completed at approximately $138^{\circ} \mathrm{C}$. At this stage, there was a big decrease in the sample weight as much as $47.4 \%$. This decrease is probably caused by the moisture in the body of the sample. Endothermic $27 \%$ weight loss that occurs between $138-249^{\circ} \mathrm{C}$ at the second step is thought to correspond to alliin which is known to have a boiling point of $167^{\circ} \mathrm{C}$ and other volatile sulphur compounds to get away from the structure. In the last step between 249 and $988^{\circ} \mathrm{C}$, the other heavy aromatic compounds in the sample $(16.2 \%$ experimental weight loss) got away from the structure and $9.5 \%$ dry product was left. The thermogram of the leaf part of Samsun sample and the graphics of the both bulb and leaf parts of the samples from all countries have the same profile.

\section{Conclusions}

Recently, the significance of medical plants has been increasing due to the side effects of chemical products and the fact that they are not economical. A. scorodoprasum subsp. rotundum, which is one of the allium plants, is a plant consumed due to its effects of prolonging the shelf life of the product, giving flavour and its health effects as well as being used as food in public. The purpose of this study was to determine the natural antioxidants of $A$. scorodoprasum subsp. Rotundum plants which is naturally grown in three different cities. In the study both the leaf and the bulb parts of the plant were analysed separately. The results of the analysis showed that the leaf parts of samples showed significant difference $(\mathrm{P}<0.05)$ in terms of the location they were grown in. The bulb parts of the samples of all cities were found to include lower antioxidant compound and antioxidant activity when compared with the leaf parts. The physicochemical characteristics, antioxidant compound and antioxidant activity values of the bulb and leaf parts of the plants were found to differ in terms of the climatic conditions and soil characteristics of the region the plants were grown.

\section{Acknowledgment}

This study has been performed for my master's degree thesis work. The authors thank Ondokuzmayis University Scientific Research Projects Unit (Project No. PYO.MUH.1904.15.022) for financial support.

\section{References}

Akinwande BA, Olatunde SJ. 2015. Comparative evaluation of the mineral profile and other selected components of onion and garlic. Int Food Res J., 22(1): 332-336.

Al-Wafi HA AK. 2005. Isolation and polymerization of allicin which is extracted from dry powder of Allium sativium (garlic). J Basrah Res., 31: 17-25.

AOAC. 2000 Official Methods of Analysis of the Association of Official Analysis Chemists. Horwitz W. (17th ed.)., Gaithersburg, Md.: AOAC International, 2000. ISBN: 0935584676 (v.1).

Ashwini M, Balaganesh J, Balamurugan S, Murugan SB, Sathishkumar R. 2013. Antioxidant activity in in vivo and in vitro cultures of onion varieties (Bellary and $\mathrm{CO} 3$ ). Food and Nutr Sci., 4: 918-923.

Colina Coca C, De Ancos B, Sánchez Moreno C. 2014. Nutritional composition of processed onion: S-Alk(en)yl-1cysteine sulfoxides, organic acids, sugars, minerals, and vitamin C. Food and Biopro Technol.,7(1): 289-298.

Fritsch RM, Blattner FR, Gurushidze M. 2010. New classification of Allium L. subg. Melanocrommyum (Webb \& Berthel) Rouy (Alliaceae) based on molecular and morphological characters. Phyton-Int J Exp Bot., 4:145-220.

Gao X, Bjärk L, Trajkovski V, Uggla M. 2000. Evaluation of antioxidant activities of rosehip ethanol extracts in different test system. J Agr Food Chem., 80: 2021-2027

Lanzotti V. 2006. The analysis of onion and garlic. J Chromatogr., 1112: 3-22.

Lee HS, Coates GA. 1999. Vitamin C in frozen, fresh squeezed, unpasteurized, polyethylene-bottled orange juice: a storage study. Food Chem., 65: 165-168.

Lu X, Wang J, Al-Qadiri HM, Ross CF, Powers JR, Tang J, Rasco BA. 2011a. Determination of total phenolic content and antioxidant capacity of onion (Allium cepa) and shallot (Allium oschaninii) using infrared spectroscopy. Food Chem., 129:637-644 DOİ:10.1016/j.foodchem.2011.04.105.

Lu X, Ross C F, Powers J R, Aston D E, Rasco, B A. 2011 b. Determination of total phenolic content and antioxidant activity of garlic (Allium sativum) and elephant garlic (Allium ampeloprasum) by attenuated total reflectanceFourier transformed infrared spectroscopy. J Agr Food Chem., 59: 5215-5221. DOI: 10.1021/jf201254f; PMID: 21506613.

Mehrabi AA, Nasab BF. 2012. In-vitro Culture of Allium scorodoprasum spp. rotundum: Callus induction, somatic embryogenesis and direct bulblet formation. Intl $\mathbf{J}$ of Agri Crop Sci., 4(1): 1-7.

Miryeganeh M, Movafeghi A.2009. Scape anatomy of Allium sect. Allium (Alliaceae) in Iran. JSUT., 35(1): 1-5.

Mitic V D, Stankov-Jovanovic VP, Ilic MD, Cvetkovic JS, Dimitrijevic MV, Stojanovic GS. 2014. In vitro antioxidant activity of methanol extract of Allium scorodoprasum. Bulg J Agric Sci., 20: 1130-1136. 
Mladenovic JD, Maskovic P Z, Pavlovic RM, Radovanovic BC, Acamovic-Đokovic G, Cvijovic MS. 2011. Antioxidant activity of ultrasonic extracts of leek Allium porrum L. Hem Ind., 65(4): 473-477.

Pardo JE, Escribano J, Gómez R, Alvarruiz A. 2007. Physicalchemical and sensory quality evaluation of garlic cultivars. J Food Qual., 30: 609-622.

Pehlivan M, Sevindik M. 2018. Antioxidant and antimicrobial activities of Salvia multicaulis. Turkish Journal of Agriculture-Food Science and Technology, 6(5): 628-631.

Pirak T, Jangchudi A, Jantawat P. 2012. Characterisation of physical, chemical and antimicrobial properties of allicinchitosan complexes., Int J Food Sci Tech., 47:1339-1347. DOI:10.1111/j.1365-2621.2012.02978.x

Sahu SC. 2002. Dual role of organosulfur compounds in foods. J Env Sci Health, 20:61-76. DOI: 10.1081/GNC-120005388; PMID: 12734054.

Sevindik M, Akgul H, Pehlivan M, Selamoglu Z. 2017. Determination of therapeutic potential of Mentha longifolia ssp. longifolia. Fresen Environ Bull, 26(7): 4757-4763.
Songsungkan J, Chanthai S. 2014. Determination of synergic antioxidant activity of the methanol/ethanol extract of allicin in the presence of total phenolics obtained from the garlic capsule compared with fresh and baked garlic clove. IFRJ, 21: $2377-2385$

Tural S, Koca I. 2008. Physico-chemical and antioxidant properties of cornelian cherry fruits (Cornus mas L.) grown in Turkey. Sci Hortic., DOI:116:362-366 10.1016 /j.scienta.2008.02.003.

Venkadachalam K, Rangasamy R, Krishnan V. 2014. Total antioxidant activity and radical scavenging capacity of selected fruits and vegetables from South India. IFR.J, 21(3): 1003-1007.

Zouari S, Ketata M, Boudhrioua N, Ammar E. 2013. Allium roseum L. volatile compounds profile and antioxidant activity for chemotype discrimination-case study of the wild plant of Sfax (Tunisia). Ind Crop Prod., 41:172-178. 